\title{
Isolation and Characterization of the Bioactive Compound of Piperine in Black Pepper (Piper nigrum L.)
}

\author{
${ }^{*}$ Nora Listantia, bFaizul Bayani \\ ${ }^{a}$ Mathematic Education Study Program, ${ }^{b}$ Pharmacy Study Program, Universitas Qamarul \\ Huda Badaruddin Bagu, Jl. H. Badaruddin Desa Bagu 83562, Indonesia \\ *Corresponding Author e-mail: noralistantia@gmail.com
}

Received: November 2021; Revised: December 2021; Published: December 2021

\begin{abstract}
One of the most famous spice species that lives in the tropics is black pepper (Piper nigrum L.). The study of piperine paved the way for its development as a bioactive compound in the treatment of various diseases, this is based on the ancient healing tradition of using black pepper. Our current study aims to isolate and characterize the bioactive compound piperine in Piper nigrum L. Black pepper was extracted with ethanol using the basic soxhletation and percolation methods. The results in the study showed that the extract from the Sokhlet process was yellowish moss green, and the piperine crystal color was yellow and shaped like a needle. Thin layer chromatography (TLC) results were observed using a UV-Vis spectrophotometer with different eluents and different Rf values were obtained. In addition, observations on the IR spectrum show that the piperine structure has been formed. This study provides an opportunity for a more in-depth exploration of the structure of piperine and future studies are very important to identify the potential utilization of piperine, especially as a basic material in the treatment of various diseases.
\end{abstract}

Keywords: Isolation, characterization, bioactive compound, piperine

How to Cite: Listantia, N., \& Bayani, F. (2021). Isolation and Characterization of the Bioactive Compound of Piperine in Black Pepper (Piper nigrum L.). Prisma Sains : Jurnal Pengkajian Ilmu dan Pembelajaran Matematika dan IPA IKIP Mataram, 9(2), 396-401. doi:https://doi.org/10.33394/j-ps.v9i2.4608

https://doi.org/10.33394/j-ps.v9i2.4608

Copyright $\odot$ 2021, Ramdani et al This is an open-access article under the CC-BY License.

\section{INTRODUCTION}

Since the beginning of human life, spices have been an important supporting part of nutrition, and for thousands of years have been used to improve the aroma and taste of food, it is also used as a preservative (Nagalingam et al., 2015). One of the most famous spice species that lives in the tropics is Piper (from the family Piperaceae) (Scott et al., 2007). Piper nigrum L. or pepper, has long been nicknamed the "king of spices" (Takooree et al., 2019), its because of the benefits in supporting human life, for example for herbal remedies, insecticides, preservatives and many other benefits (Wang et al., 2019). So it is not surprising that in the global market the share of P. nigrum trade is very large (Srinivasan, 2007). In 2016, Indonesia was the second largest producer of P. nigrum in the world (first Vietnam), with a total production of P. nigrum in Indonesia of 70,000 metric tons. Until now, P. nigrum continues to be cultivated and production continues to be increased (Hussain, 2017).

Piperine is a natural compound responsible for the pungent smell and taste found in black pepper (P nigrum) together with chavicine (a geometric isomer of piperine) (Butt et al., 2013). The results of previous studies summarized by Chavarria et al. (2016) show that the current study of piperine is paving the way for its development as a bioactive compound in the treatment of various diseases. The results of a review by Takooree et al. (2019) on 65 treatment processes that utilize P. nigrum, show that piperine compounds can be used to treat 
menstrual disorders, ear-nose-throat (ENT), gastrointestinal, skin diseases, and fever (the distribution can be seen in Figure 1).

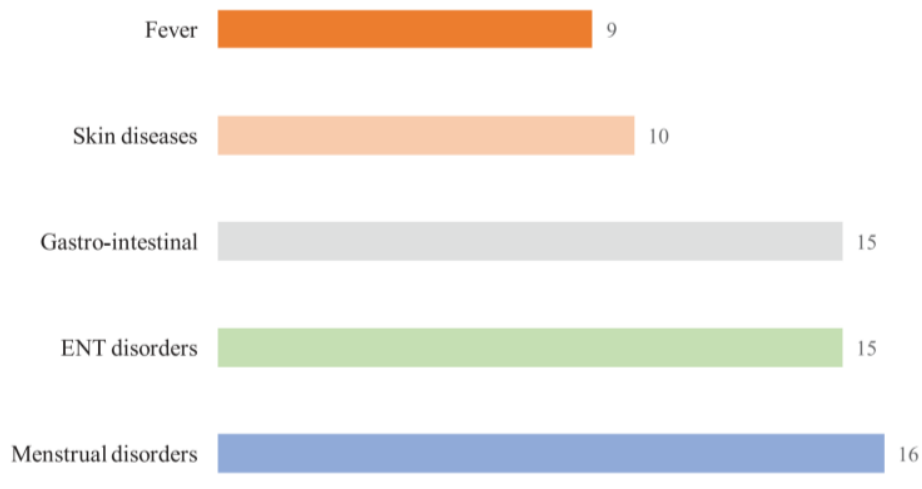

Figure 1. Utilization of P. nigrum for the treatment of disease

However, it is recognized that the development of bioactive compounds in piperine is still at an early stage. Therefore, continuous exploration needs to be carried out, especially on its structure so that it can be utilized in various piperine-based new drug discoveries (Chavarria et al., 2016).

Piperine $\left(\mathrm{C}_{17} \mathrm{H}_{19} \mathrm{NO}_{3}\right)$ is a colorless or slightly yellowish, shiny, prismatic crystalline compound, odorless and almost tasteless when first placed in the mouth but on prolonged contact it causes a sharp, stinging sensation on the tongue. Piperine is almost insoluble in water, soluble in 30 parts of alcohol at $15^{\circ} \mathrm{C}\left(59^{\circ} \mathrm{F}\right)$ and in 1 part of heated alcohol. Alcoholic solutions of piperine are neutral on litmus paper. Piperine is also soluble in chloroform, benzene, carbon disulfide but almost insoluble in petroleum ether. Black pepper consists of carbohydrates, protein, fiber, water content, and fat with percentages of $37.4 \%, 25.5 \%$, $23.6 \%, 4.7 \%$, and $5.3 \%$, respectively. Some of the mineral content, including $\mathrm{K}, \mathrm{Ca}, \mathrm{P}$ and Mg (Al-Jasass \& Al-Jasser, 2012; Pradeep et al., 1993).

To get the pure bioactive compound piperine in a plant or natural material, an isolation process is needed. The isolation process is a series of extraction, separation, and purification processes of a compound in a material. Piperine is a compound that is quite easily isolated from black pepper, either through the percolation/maceration process or by Soxhlet extraction with organic solvents such as ethanol. To obtain pure piperine compounds, recrystallization (the process of dissolving and crystallizing repeatedly) was carried out with acetone-hexane (3:2). To determine the compound formed is piperine, it can be determined the nature of the UV spectrum with a spectrophotometer, as well as the $\mathrm{Rf}$ value based on Thin Layer Chromatography (TLC) (Kusumorini et al., 2021). Our current study aims to isolate and characterize the bioactive compound piperine in Piper nigrum $\mathrm{L}$.

\section{METHOD}

The tools used are a set of Soxhlet equipment with heater, rotary evaporator, $100 \mathrm{~mL}$ beaker, $100 \mathrm{~mL}$ Erlenmeyer, $50 \mathrm{~mL}$ measuring cup and UV-Vis Spectrophotometer. The materials were prepared, namely black pepper powdered $100 \mathrm{~g}$, ethanol, 10\% KOH-ethanol, filter paper or lead, acetone, and hexane.

The procedure for the isolation and characterization process was to grind black pepper by finely grinding and extracting it in a Soxhlet extractor, using $150 \mathrm{~mL}$ of ethanol for approximately 2 hours. Concentrate the ethanol extract in a rotary evaporator at $60^{\circ} \mathrm{C}$ until dry. Add $10 \% \mathrm{KOH}$-ethanol to the dry extract. After some time (approximately 5 minutes) the base fraction/filtrate was decanted into an erlenmeyer and left overnight in a cold 
cupboard/refrigerator. Next, filter the formed crystals and dry them with filter paper to produce dry crystals. To obtain purer crystals, recrystallization was carried out with $10 \mathrm{~mL}$ of acetone-hexane (3:2) solution, where the crystals were redissolved and stored in the refrigerator for one night. Filter the obtained crystals and dry on filter paper. Finally, save the crystal for characterization.

\section{RESULTS AND DISCUSSION}

Black pepper (black pepper) was extracted with ethanol using the basic method of soxhletation and percolation. The resulting ethanol extract was concentrated with a rotary evaporator which produced a concentrated extract. In this study, the filter used was ethanol. Ethanol is considered as a filter because it is more selective, molds and germs are difficult to grow, non-toxic, neutral, absorbs well, ethanol is miscible with water in all ratios, and the heat required for concentration is relatively less. The results of the extract of black pepper are yellowish green in color with the extraction process 6 times. In the soxhlet in which there is water coming out, water entering, solvent, and the sample being wrapped there are channels that drain the steam and drain the extract.

Extraction or filtration is a mass transfer event of substances that were originally inside drawn by the liquid filter so that the active substances dissolve in the liquid filter. While the extract is a concentrated preparation obtained by extracting the active substance from vegetable simplicia. From the extraction results obtained dilute ethanol which needs to be concentrated by vacuum evaporation. The concentrated extract was dissolved in $10 \% \mathrm{KOH}$ in ethanol, so that a $10 \%$ ethanol- $\mathrm{KOH}$ solution containing piperine was obtained. When the solution is cooled it will form yellow crystals that are still dirty. For piperine purification, recrystallization was carried out by dissolving and crystallizing repeatedly with acetonehexane 3:2. The color of the resulting crystal is yellow with a needle-like shape.

Based on observations, data obtained that the weight of black pepper used is 100 grams, the number of extraction rounds is more than 6 rounds, the color of the extract resulting from the Sokhlet process is yellowish moss green, the piperine crystal color is yellow and shaped like a needle. The TLC results were observed with a UV-Vis spectrophotometer to determine the Rf value. The eluents used in TLC are 4 kinds of eluents, as presented in Table 1, and the results of observations of TLC with various eluents are presented in Figure 1.

Table 1. Rf value for each eluent

\begin{tabular}{lcc}
\hline \multirow{2}{*}{ Eluen } & \multicolumn{2}{c}{$\mathrm{Rf}$} \\
\cline { 2 - 3 } & $\begin{array}{c}\text { Based on piperine crystal sample } \\
\text { distance }\end{array}$ & $\begin{array}{c}\text { Based on the sample distance of } \\
\text { piperine oil fraction }\end{array}$ \\
\hline Hexan & 0.45 & 0.60 \\
Aseton & 0.67 & 0.69 \\
Hexan-aseton & 0.70 & 0.73 \\
Methanol & 0.73 & 0.70 \\
\hline
\end{tabular}

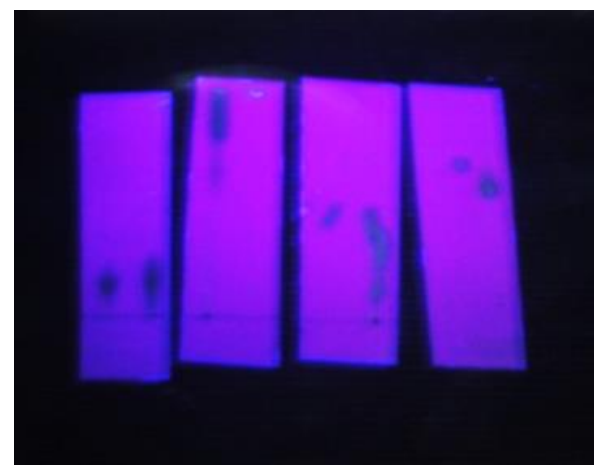

Figure 1. Results of TLC observations with various eluents 
In our study, thin layer chromatography (TLC) was used with different types of eluent plates, namely using hexane, acetone, and methanol. Chromatography is a molecular separation technique based on differences in movement patterns between the mobile phase and the stationary phase to separate the components (molecules) in solution (Coskun, 2016). Molecules dissolved in the mobile phase will pass through the column which is the stationary phase. Molecules that have strong bonds with the column will tend to move more slowly than molecules with weak bonds. With this, various types of molecules can be separated based on the movement in the column. The thin layer method has the main advantages, namely that it requires faster time and better separation is obtained (Šegan et al., 2019). For qualitative separations on small plates it takes about 5 minutes. Thin layer chromatography has a larger capacity and its absorption system can be used to separate hydrophobic compounds.

In the purification process, pure compounds are produced by determining the structure of the compounds using a UV-Vis spectrophotometer. From the observations obtained TLC results with various eluents. Hexan with a value of $\mathrm{Rf}=0.45$ (piperine crystals) and $\mathrm{Rf}=0.60$ (piperine oil fraction). In hexane, the oil fraction is lower and lasts longer. This is influenced by the nature of the absorption and the degree of activity. The difference in absorption will give a large difference to the value of Rf even though the use of the mobile phase and the same solute is used, but the results will be repeated with the same results, which will only be obtained if using the same absorption and fixed particle size and if the binder is mixed until homogeneous. Acetone with $\mathrm{Rf}=0.67$ (piperine crystals) and $\mathrm{Rf}=0.69$ (piperine oil fraction). In general the method of coating colorless compounds on thin films is similar to that of paper chromatography by immersion. This is due to the flatness and thickness of the absorbent layer, although in this practicum the effect of the thickness of the layer cannot be seen but it is necessary to strive so that the thickness of the layer is even. The unevenness will cause the solvent flow to be uneven as well as a small area of the plate.

In acetone eluent, the oil fraction is higher so that a lot of it is carried away. Hexanacetone with $\mathrm{Rf}=0.70$ (piperine crystals) and $\mathrm{Rf}=0.73$ (piperine oil fraction). When a mixed solvent is used, swelling will occur with a concave surface of the solvent and the mobile phase will move faster at the edges than in the middle so that the $\mathrm{Rf}$ value in the oil fraction is larger than the other eluents. Methanol with a value of $\mathrm{Rf}=0.73$ (piperine crystals) and $\mathrm{Rf}=$ 0.70 (piperine oil fraction). With the oil fraction lower than the crystal, it means the oil fraction is low and stops. Methanol as an eluent has volatile properties so that the separation carried out is very dependent on temperature, this is to prevent changes in solvent composition caused by evaporation or phase changes. The alleged structure of piperine that appears in the IR spectrum is shown in Figure 2.

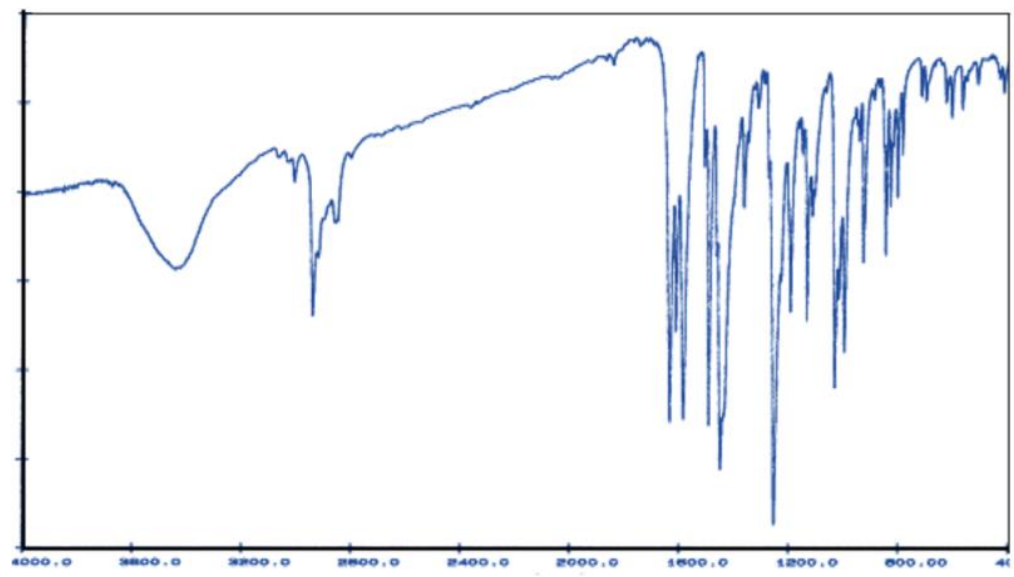

Figure 2. The structure of piperine that appears in the IR spectrum 
The valence of $\mathrm{C}-\mathrm{H}$ bonds, arenes/aromatic hydrocarbons, alkenes lies at $\mathrm{V}=3965$ $3010 \mathrm{~cm}^{-1}$ which is brond (width) and has a lot of absorption. The valence of $\mathrm{C}-\mathrm{H}$ bonds, alkanes lies at $\mathrm{V}=2940-2850 \mathrm{~cm}^{-1}$. The valence of the $\mathrm{C}=\mathrm{O}$ bond, Carboxyl amine acid is located at $\mathrm{V}=1635 \mathrm{~cm}^{-1}$ which is down feel (away from) so that the frequency is large. The valence of the $\mathrm{C}=\mathrm{C}$ bond, alkane, arene lies at $\mathrm{V}=1610 \mathrm{~cm}-1$ and the valence of the $\mathrm{C}=\mathrm{C}$ bond, arene is located at $\mathrm{V}=1580 \mathrm{~cm}^{-1}$ and $1490 \mathrm{~cm}^{-1}$.

\section{CONCLUSION}

Based on the results of this study, it can be concluded that the color of the extract resulting from the Sokhlet process is yellowish moss green and the color of piperine crystals is yellow and shaped like a needle. Thin layer chromatography (TLC) results were observed using a UV-Vis spectrophotometer with different eluents and different $\mathrm{Rf}$ values were obtained. In addition, observations on the IR spectrum show that the piperine structure has been formed.

\section{RECOMMENDATION}

This study provides an opportunity for a more in-depth exploration of the structure of piperine and future studies are very important to identify the potential use of piperine, especially as a basic material in the treatment of various diseases.

\section{ACKNOWLEDGEMENT}

The researcher would like to thank those who have contributed and helped the process of this study.

\section{REFERENCES}

Al-Jasass, F. M., \& Al-Jasser, M. S. (2012). Chemical Composition and Fatty Acid Content of Some Spices and Herbs under Saudi Arabia Conditions. The Scientific World Journal, 2012, 1-5. https://doi.org/10.1100/2012/859892

Butt, M. S., Pasha, I., Sultan, M. T., Randhawa, M. A., Saeed, F., \& Ahmed, W. (2013). Black pepper and health claims: A comprehensive treatise. Critical Reviews in Food $\begin{array}{llr}\text { Science } \quad \text { Nutrition, } & \text { 83(9), }\end{array}$ https://doi.org/10.1080/10408398.2011.571799

Chavarria, D., Silva, T., Magalhães e Silva, D., Remião, F., \& Borges, F. (2016). Lessons from black pepper: Piperine and derivatives thereof. Expert Opinion on Therapeutic Patents, 26(2), 245-264. https://doi.org/10.1517/13543776.2016.1118057

Coskun, O. (2016). Separation techniques: Chromatography. Northern Clinics of Istanbul, 3(2), 156-160. https://doi.org/10.14744/nci.2016.32757

Hussain, M. (2017). Evaluation of Local Black Pepper (Piper nigrum L.) Genotypes for Yield and Quality under Arecanut Based Cropping System. International Journal of Pure \& Applied Bioscience, 5(5), 1396-1400. https://doi.org/10.18782/2320-7051.5809

Kusumorini, N., Nugroho, A. K., Pramono, S., \& Martien, R. (2021). Development of New Isolation and Quantification Method of Piperine from White Pepper Seeds (Piper Nigrum L) Using A Validated HPLC. Indonesian Journal of Pharmacy, 32(2), 158165. https://doi.org/10.22146/ijp.866

Nagalingam, M., Arumugam, G., \& Panneerselvam, A. (2015). Antimicrobial activity of some Indian folklore medicinal plants against drug resistant bacteria and fungi isolated from clinical samples. Asian Journal of Plant Science and Research, 5(6), 49-56. 
Pradeep, K. U., Geervani, P., \& Eggum, B. O. (1993). Common Indian spices: Nutrient composition, consumption and contribution to dietary value. Plant Foods for Human Nutrition, 44(2), 137-148. https://doi.org/10.1007/BF01088378

Scott, I. M., Helson, B. V., Strunz, G. M., Finlay, H., Sánchez-Vindas, P. E., Poveda, L., Lyons, D. B., Philogène, B. J. R., \& Arnason, J. T. (2007). Efficacy of Piper nigrum (Piperaceae) extract for control of insect defoliators of forest and ornamental trees. The Canadian Entomologist, 139(4), 513-522. https://doi.org/10.4039/n06-040

Šegan, S., Opsenica, D., \& Milojković-Opsenica, D. (2019). Thin-layer chromatography in medicinal chemistry. Journal of Liquid Chromatography \& Related Technologies, 42(9-10), 238-248. https://doi.org/10.1080/10826076.2019.1585615

Srinivasan, K. (2007). Black Pepper and its Pungent Principle-Piperine: A Review of Diverse Physiological Effects. Critical Reviews in Food Science and Nutrition, 47(8), 735748. https://doi.org/10.1080/10408390601062054

Takooree, H., Aumeeruddy, M. Z., Rengasamy, K. R. R., Venugopala, K. N., Jeewon, R., Zengin, G., \& Mahomoodally, M. F. (2019). A systematic review on black pepper (Piper nigrum L.): From folk uses to pharmacological applications. Critical Reviews in Food Science and Nutrition, 59(sup1), S210-S243. https://doi.org/10.1080/10408398.2019.1565489

Wang, M., Chittiboyina, A. G., Parcher, J. F., Ali, Z., Ford, P., Zhao, J., Avula, B., Wang, Y.H., \& Khan, I. A. (2019). Piper nigrum Oil-Determination of Selected Terpenes for Quality Evaluation. Planta Medica, 85(3), 185-194. https://doi.org/10.1055/a-07820548 